\title{
PENGARUH MODEL PEMBELAJARAN PEER TEACHING TERHADAP PENINGKATAN ASPEK AFEKTIF MAHASISWA PADA MATA KULIAH AKUNTANSI KEUANGAN PROGRAM STUDI PERBANKAN SYARIAH UNIVERSITAS MUHAMMADIYAH SUMATERA UTARA
}

\author{
Isra Hayati \\ israhayati@umsu.ac.id \\ Dian Novianti Sitompul \\ diannovianti@umsu.ac.id
}

\author{
UNIVERSITAS MUHAMMADIYAH SUMATERA UTARA \\ Jln Kapten Mukhtar Basri No 3 Medan
}

\begin{abstract}
The purpose of this research is (1) to know the influence of peer teaching learning model to improve affective aspect of students in Financial Accounting course of Islamic Banking Study Program of Muhammadiyah University of North Sumatera (2) to know how big influence of peer teaching model to increasing affective aspect of student at Financial Accounting courses of Islamic Banking Studies University of Muhammadiyah Sumatera Utara. The method used in this research is quasi experiment with control group research pretest posttest design. After hypothesis testing by using Paired Sample T-Test technique, the significance (2-tailed) count is 0,001 at significance level $<0,05$ Thus $\mathrm{H} 1$ is accepted and $\mathrm{HO}$ is rejected because of significance $<0,05$. So it can be concluded that there is influence of learning model of peer teaching on improving affective aspects of students in the subject of Financial Accounting courses of Islamic Banking University of Muhammadiyah North Sumatra. To see the improvement of the cognitive aspects achieved by the students used normalized $\mathrm{N}$-Gain data. Improvement of student cognitive aspect that can be revealed, that is: mean of $\mathrm{N}$-Gain score of affective aspect of student in experimental class 0,6593 whereas mean of $\mathrm{N}$-Gain affective aspect of student in control class 0,4096. Improved affective aspects of students in the experimental and control classes belong to the moderate category.
\end{abstract}

Keyword: peer teaching, affective, learning model 
Isra Hayati dan Dian Novianti Sitompul_Pengaruh Model Pembelajaran Peer Teaching Terhadap Peningkatan Aspek Afektif Mahasiswa Pada Mata Kuliah Akuntansi Keuangan Program Studi Perbankan Syariah Universitas Muhammadiyah Sumatera Utara

\section{PENDAHULUAN}

Mata Kuliah Akuntansi Keuangan merupakan mata kuliah yang berhubungan dengan penyajian laporan keuangan perusahaan kepada pihak eksternal berupa laporan neraca, rugi laba, perubahan modal dan arus kas kepada pemegang saham, kreditor atau investor khususnya tentang profitabilitas dan kredibilitas perusahaan, kepada supplier ataupun pemerintah. Proses pembelajaran mata kuliah akuntansi keuangan pada perguruan tinggi terkesan sulit disebabkan ilmu akuntansi secara jelas membedakan pokok - pokok masalah dan memasukkan keseragaman serta keteraturan yang mendasari hubungan empirik, penyamarataan secara otoritatif, konsep - konsep, prinsip, aturan - aturan maupun teori teori (Belkaoui 2001). Sedangkan mahasiswa yang belajar mata kuliah akuntansi keuangan pada perguruan tinggi sebagian besar berasal dari multi disiplin ilmu pada tingkat Sekolah Menengah Atas, ditambah lagi sebagian besar dosen menggunakan metode ceramah dan minim memanfaatkan keberagaman model pembelajaran.

Airasian (2010) menyebutkan bahwa pembelajaran menekankan pada model untuk membuat peserta didik menyadari dan bertanggungjawab atas pengetahuan dan pemikiran mereka sendiri. Undang-undang Nomor 20 Tahun 2003 tentang Sistem Pendidikan Nasional, Pasal 1 angka 1 menyatakan bahwa pendidikan adalah usaha sadar dan terencana untuk mewujudkan suasana belajar dan proses pembelajaran agar peserta didik secara aktif mengembangkan potensi dirinya untuk memiliki kekuatan spiritual keagamaan, pengendalian diri, kepribadian, kecerdasan, akhlak mulia, serta keterampilan yang diperlukan dirinya, masyarakat, bangsa dan negara. Proses pembelajaran diperguruan tinggi harus diselenggarakan secara interaktif, inspiratif, menyenangkan, menantang, memotivasi peserta didik untuk berpartisipasi aktif, serta memberikan ruang yang cukup bagi prakarsa, 
Isra Hayati dan Dian Novianti Sitompul_Pengaruh Model Pembelajaran Peer Teaching Terhadap Peningkatan Aspek Afektif Mahasiswa Pada Mata Kuliah Akuntansi Keuangan Program Studi Perbankan Syariah Universitas Muhammadiyah Sumatera Utara

kreativitas, dan kemandirian sesuai dengan bakat, minat, dan perkembangan fisik serta psikologis peserta didik.

Oleh sebab itu, dalam proses pembelajaran dibutuhkan upaya peningkatan pembelajaran siswa dan evaluasinya dari berbagai segi, yaitu segi kognitif, afektif, dan psikomotor. Seperti yang diungkapkan Benjamin S. Bloom (dalam Hamzah B. Uno, 2008) mengkategorikan hasil belajar dalam tiga ranah atau kawasan yaitu (1) ranah kognitif (cognitive domain), (2) ranah afektif (affective domain), dan (3) ranah psikomotorik (motor skill domain). Proses pembelajaran pada saat ini kebanyakan yang diukur adalah kemampuan aspek kognitif semata, sedangkan dari aspek afektifnya hanya sedikit diberikan pada saat proses pembelajaran. Padahal aspek afektif juga penting untuk pembentukan karakter mahasiswa sehubungan dengan kurikulum pendidikan tinggi yang diterapkan pada proses pembelajaran perguruan tinggi.

Temuan yang menunjukkan bahwa aspek afektif mahasiswa yang masih rendah pada saat proses pembelajaran terlihat dari hal-hal yang dilakukan mahasiswa sebagai berikut:

1. Sikap penerimaan, pada sikap penerimaan mahasiswa kurang tertarik mendengar penjelasan dari dosen terkait dengan materi perkuliahan.

2. Sikap partisipasi, pada sikap partisipasi mahasiswa masih kurang baik, hal ini terlihat pada saat dosen usai menyampaikan materi perkuliahan, mahasiswa tidak memberikan respon terhadap penjelasan materi yang telah disampaikan dosen dari segi menjawab dan memberikan pertanyaan kedosen.

3. Penentuan sikap, penentuan sikap mahasiswa terhadap rangsangan yang datang masih rendah. Hal ini ditunjukkan dengan kurangnya rasa peduli dan tanggung jawab mahasiswa dalam menyelesaikan tugas yang diberikan oleh dosen.

4. Sikap organisasi, sikap organisasi yang dimiliki mahasiswa masih rendah. Hal ini ditunjukkan dengan masih banyaknya mahasiswa yang tidak dapat membentuk dirinya agar siap mengikuti 
Isra Hayati dan Dian Novianti Sitompul_Pengaruh Model Pembelajaran Peer Teaching Terhadap Peningkatan Aspek Afektif Mahasiswa Pada Mata Kuliah Akuntansi Keuangan Program Studi Perbankan Syariah Universitas Muhammadiyah Sumatera Utara

perkuliahan, mahasiswa menunggu arahan dari dosen dalam memulai perkuliahan.

5. Sikap pembentukan pola hidup, sikap pembentukan pola hidup mahasiswa juga belum menunjukkan hal yang positif. Hal ini ditunjukkan dengan minimnya pembendaharaan pengetahuan mahasiswa terhadap materi pembelajaran karena mahasiswa tidak mempunyai catatan ataupun buku pegangan,bahkan mahasiswa kurang berminat mengunjungi perpustakaan.

Oleh sebab itu, dosen harus mempunyai kreativitas tinggi dalam memilih model pembelajaranyang menarik minat mahasiswa. Ada dugaan bahwa pola pembelajaran secara parsial dari sistem dan prosedur saat mengikuti kuliah - kuliah prasyarat untuk mengikuti praktikum akuntansi menimbulkan ketidak mampuan mahasiswa menggabungkan kemampuan kuliah - kuliah prasyarat itu menjadi satu kesatuan yang tersistem sebagai kegiatan yang prosedural dan sistematik. Akibatnya uji transfer dari penguasan kemampuan para mahasiswa dalam menghubungkan semua mata kuliah akuntansi masih lemah seperti mata kuliah pengantar akuntansi, akuntansi keuangan, akuntansi biaya dan akuntansi syariah.

Salah satu model pembelajaran kooperatif yang dapat meningkatkan aspek afektif mahasiswa yaitu model pembelajaran peer teaching. Pembelajaran peer teaching adalah pembelajaran yang terpusat pada mahasiswa, dalam hal ini mahasiswa belajar dari mahasiswa lain yang memiliki status umur, kematangan/ harga diri yang tidak jauh berbeda dari dirinya sendiri. Sehingga anak tidak merasa begitu terpaksa untuk menerima ide-ide dan sikap dari "gurunya" yang tidak lain adalah teman sebayanya itu sendiri. Dalam tutor sebaya, teman sebaya yang lebih pandai memberikan bantuan belajar kepada teman-teman sekelasnya di sekolah. Bantuan belajar oleh teman sebaya dapat menghilangkan kecanggungan

Model pembelajaran peer teaching memfasilitasi mahasiswa dengan kemampuan yang berbeda-beda. Mahasiswa yang mempunyai 
Isra Hayati dan Dian Novianti Sitompul_Pengaruh Model Pembelajaran Peer Teaching Terhadap Peningkatan Aspek Afektif Mahasiswa Pada Mata Kuliah Akuntansi Keuangan Program Studi Perbankan Syariah Universitas Muhammadiyah Sumatera Utara

daya tanggap lebih tentang materi yang dipelajari, dapat menunjukkan kepedulian dan tanggung jawabnya terhadap teman-temannya. Sehingga mahasiswa dapat mengaktualisasikan kemampuan lebihnya. Model pembelajaran tutor sebaya (peer Teaching) adalah model pembelajaran dalam bentuk pemberian bimbingan, bantuan, petunjuk, arahan, dan motivasi agar siswa belajar efektif dan efesien (Hamalik, 2009). Subjek yang memberikan bimbingan dalam kegiatan tutorial dikenal sebagai tutor. Tutor sebaya (Peer Teaching) adalah seseorang atau beberapa orang siswa yang ditunjuk oleh guru sebagai pembantu guru dalam melakukan bimbingan terhadap teman sekelas agar dapat meningkatkan hasil belajar (Arikunto, 2008).

Pembelajaran sekarang harus melibatkan otak untuk berfikir disebut sebagai aspek kognitif dan hati untuk merasakannya disebut sebagai aspek afektif (Singgih, 2013). Aspek kognitif mencakup tingkat kecerdasan, daya kreatifitas, bakat khusus, kemampuan berbahasa, daya fantasi dan gaya belajar (Poerwanti dan Widodo, 2012). Aspek afektif berhubungan dengan penggunaan hati. Yang harus menggunakan hati dalam proses pembelajaran tidak hanya siswa, tetapi juga guru (Jagiyanto, 2006). Sikap guru lebih ditekankan ketika proses belajar mengajar berlangsung. Guru mempunyai kewenangan untuk menciptakan suasana dan iklim dikelas.

Dengan adanya model pembelajaran peer teaching, mahasiswa tidak perlu hanya bergantung kepada dosen tetapi dapat belajar secara mandiri maupun kelompok untuk saling bertukar fikiran dengan teman sekelasnya sehingga dapat meningkatkan aspek kognitif dan aspek afektif mahasiswa.

Berdasarkan uraian diatas, tujuan penelitian ini adalah untuk menemukan bukti empiris: "Pengaruh Model Pembelajaran Peer Teaching Terhadap Peningkatan Afektif Mahasiswa Pada Mata Kuliah Akuntansi Keuangan Program Studi Perbankan Syariah Universitas Muhammadiyah Sumatera Utara". Penelitian ini diharapkan dapat memberikan kontribusi terhadap pengayaan pengajaran dalam 
Isra Hayati dan Dian Novianti Sitompul_Pengaruh Model Pembelajaran Peer Teaching Terhadap Peningkatan Aspek Afektif Mahasiswa Pada Mata Kuliah Akuntansi Keuangan Program Studi Perbankan Syariah Universitas Muhammadiyah Sumatera Utara

pembelajaran mata kuliah akuntansi keuangan sehingga kualitas pembelajaran bermakna dapat diterima mahasiswa dengan baik.

\section{TINJAUAN PUSTAKA}

\subsection{Teori Pembelajaran Kooperatif}

Pembelajaran kooperatif sesuai dengan fitrah manusia sebagai sosial yang penuh ketergantungan dengan orang lain, mempunyai tujuan dan tanggung jawab bersama, pembagian tugas, dan rasa senasib. Dengan memanfaatkan kenyatan itu, belajar berkelompok secara kooperatif, siswa dilatih dan dibiasakan untuk saling berbagi (sharing) pengetahuan, pengalaman, tugas, dan tanggung jawab. Saling membantu dan berlatih berinteraksi-komunikasi- sosialisasi karena kooperatif adalah miniatur dari hidup bermasyarakat, dan belajar menyadari kekurangan dan kelebihan masing-masing. Allan C. Ornstein (2000) mengungkapkan:

Cooperative learning offers many benefit: for students, itim proves both academic learning and social skills; for teachers, itis an aidt o classroom management an dinstruction. Cooperative learning enhances student's enthusiasm for learning and their determination to achieve academic success.

Jadi, pembelajaran kooperatif dapat menumbuhkan kemampuan belajar dan kemampuan bersosialisasi juga dapat menumbuhkan antusias atau minat siswa dalam mengikuti pembelajaran. Hal tersebut hampir sama dengan pendapat Hwang, G.-J., Yin, P.-Y., Hwang, C.-W., \&Tsai, C.-C. (2008) yang menyatakan bahwa:

Cooperative learning is known tobe an effective education alstrategy in enhancing the learning performance of students. The goal of a cooperative learning group is to maximize allmembers' learning efficacy. This is accomplished via promoting each other's success, through assisting, sharing, mentoring, explaining, and encouragement.

Dengan demikian, pembelajaran kooperatif dikenal sebagai 
Isra Hayati dan Dian Novianti Sitompul_Pengaruh Model Pembelajaran Peer Teaching Terhadap Peningkatan Aspek Afektif Mahasiswa Pada Mata Kuliah Akuntansi Keuangan Program Studi Perbankan Syariah Universitas Muhammadiyah Sumatera Utara

strategi pembelajaran yang efektif dalam meningkatkan partisipasi siswa. Tujuan kelompok dalam pembelajaran kooperatif adalah memaksimalkan agar semua siswa bisa lebih baik.Setiap siswa yang pandai mengajak yang lainnya agar sukses, melalui membantu, berbagi, menasehati, menjelaskan, dan memberikan semangat.

\subsection{Teori Model Pembelajaran Peer Teaching}

Peer Teaching (Tutor Sebaya) adalah seorang siswa pandai yang membantu belajar siswa lainnya dalam tingkat kelas yang sama (Djalil 2013). Peer Teaching (Tutor Sebaya) merupakan salah satu dari strategi pembelajaran yang berbasis active elearning. Beberapa ahli percaya bahwa satu pelajaran benar-benar dikuasai hanya apabila peserta didik mampu mengajarkan pada peserta didik lainnya. Mengajar teman sebaya memberikan kesempatan dan mendorong pada peserta didik mempelajari sesuatu dengan baik, dan pada waktu yang sama ia menjadi nara sumber bagi yang lain. Pembelajaran peerteaching merupakan cara yang efektif untuk menghasilkan kemampuan mengajar teman sebaya (Melvi, 2012).

Dipandang dari tingkat partisipasi aktif siswa, keuntungan belajar secara berkelompok dengan tutor sebaya mempunyai tingkat partisipasi aktif siswa lebih tinggi (Ratno, 2007). Proses belajar tidak harus berasal dari guru ke siswa, melainkan dapat juga siswa saling mengajar sesama siswa lainnya (Mujhinem, 2010). Pengajaran oleh rekan sebaya (peer teaching) ternyata lebih efektif dari pada pengajaran oleh guru (Huijser, 2008). Hal ini disebabkan latar belakang, pengalaman para siswa mirip satu dengan lainnya dibanding dengan guru.

Adakalanya seorang siswa lebih mudah menerima keterangan yang diberikan oleh kawan sebangku atau kawan yang lain karena tidak adanya rasa enggan atau malu untuk bertanya, guru dapat meminta bantuan kepada anak-anak yang menerangkan kepada kawan-kawannya (Arikunto, 2008). Pelaksanaan ini disebut Peer Tutoring (Tutor Sebaya) karena mempunyai usia yang hampir sebaya. 
Isra Hayati dan Dian Novianti Sitompul_Pengaruh Model Pembelajaran Peer Teaching Terhadap Peningkatan Aspek Afektif Mahasiswa Pada Mata Kuliah Akuntansi Keuangan Program Studi Perbankan Syariah Universitas Muhammadiyah Sumatera Utara

Langkah-langkah Model Peer Teaching (Tutor Sebaya) adalah:

a. Jika bantuan diberikan kepada teman sekelasnya di kelas,maka:

1) Beberapa siswa yang pandai disuruh mempelajari suatu topik

2) Guru memberi penjelasan umum tentang topik yang akan dibahasnya

3) Kelas dibagi dalam kelompok dan siswa yang pandai disebar ke setiap kelompok untuk memberikan bantuannya.

4) Guru membimbing siswa yang perlu mendapat bimbingan khusus

5) Jika ada masalah yang tidak terpecahkan, siswa yang pandai meminta bantuan kepada guru

6) Guru mengadakan evaluasi

b. Jika bantuan diberikan kepada teman sekelasnya diluar kelas, maka:

1) Guru menunjukkan siswa yang pandai untuk memimpin kelompok belajar diluar kelas.

2) Setiap siswa disuruh bergabung dengan siswa yang pandai itu, seusai dengan minat, jenis kelamin, jarak tempat tinggal, dan pemerataan jumlah anggota kelompok.

3) Guru memberikan tugas dirumah.

4) Pada waktu yang telah ditentukan hasil kerja kelompok dibahas di kelas

5) Kelompok yang berhasil baik diberi penghargaan

6) Sewaktu - waktu guru berkunjung ketempat seusai berdiskusi

7) Tempat diskusi dapat berpindah - pindah (Semiawan 2012).

\subsection{Teori Aspek Afektif}

Ranah afektif adalah ranah yang berkaitan dengan sikap dan nilai. Ranah afektif mencakup watak perilaku seperti perasaan, minat, sikap, emosi, dan nilai. Upaya peningkatan aspek afektif akan berhasil apabila penerapan guru selaku pembimbing dan fasilitator siswa dalam pembelajaran, mampu menciptakan proses pembelajaran yang memungkinkan siswa dapat merasa atau berbuat (Ivana, 2008). Ciri-ciri 
Isra Hayati dan Dian Novianti Sitompul_Pengaruh Model Pembelajaran Peer Teaching Terhadap Peningkatan Aspek Afektif Mahasiswa Pada Mata Kuliah Akuntansi Keuangan Program Studi Perbankan Syariah Universitas Muhammadiyah Sumatera Utara

hasil belajar afektif akan tampak pada peserta didik dalam lima jenjang yaitu:

1) Receiving atau attending (sikap penerimaan atau memperhatikan)

2) Responding (menanggapi) mengandung arti "adanya partisipasi aktif"

3) Valuing (penentuan sikap)

4) Organization (sikap organisasi)

5) Characterization by evalue or calue complex (sikap pembentukan pola hidup)

Sikap yang dimiliki oleh siswa sangat berpengaruh pada berbagai hasil pendidikan. Sehingga sikap siswa terhadap mata pelajaran yang diajarkan, aktivitas pembelajaran yang digunakan dan kemampuan siswa untuk menyelesaikan tugas harus dinilai secara teratur. Penilaian sikap ini dapat dilakukan dengan berbagai cara, salah satu yang digunakan untuk melakukan penilaian terhadap aspek afektif adalah dengan menggunakan lembar angket.

\section{$H_{1}$ : Model pembelajaran peer teaching berpengaruh positif terhadap peningkatan aspek afektif mahasiswa pada mata kuliah akuntansi keuangan}

Penelitian mengenai model pembelajaran peer teaching bukanlah hal yang baru dan sudah ada penelitian sebelumnya yang berkaitan dengan masalah tersebut. Namun, yang meneliti khusus pengaruh model pembelajaran peer teaching terhadap peningkatan aspek afektif mahasiswa sebagai pada mata kuliah Akuntansi Keuangan belum pernah diteliti. Berikut beberapa penelitian terdahulu yang relevan dengan penelitian ini:

1. Suntusia, S.Pd (2008), dengan judul penelitian "Pengaruh Penerapan Metode Peer Teaching Dalam Pembelajaran Fisika Terhadap Prestasi Belajar Siswa Pada Kurikulum Tingkat Satuan Pendidikan Pokok Bahasan Gelombang Elektromagnetik Kelas X Di Sma Muhammadiyah Bondowoso". Penelitian ini menunjukkan Pembelajaran fisika dengan menggunakan model Peer 
Isra Hayati dan Dian Novianti Sitompul_Pengaruh Model Pembelajaran Peer Teaching Terhadap Peningkatan Aspek Afektif Mahasiswa Pada Mata Kuliah Akuntansi Keuangan Program Studi Perbankan Syariah Universitas Muhammadiyah Sumatera Utara

Teaching dapat mengaktifkan siswa dalam pembelajaran. Hal ini ditunjukkan dengan aktivitas siswa pada siklus pertama 72,08\% dan pada siklus kedua $82 \%$ dan siklus ketiga $85 \%$. Pembelajaran dengan menggunakan model Peer Teaching diperoleh ketuntasan secara klasikal. Hal ini ditunjukkan dari 20 siswa yang tuntas belajar secra individu sebesar $85 \%$.

2. Han Bastian (2014), dengan judul penelitian "Pengaruh Model Pembelajaran Peer Teaching Terhadap Hasil Belajar Keterampilan Bermain Sepak Bola Di SMP N 1 Cimahi ". Hasil penelitian ini menunjukkan bahwa $t_{\text {hitung }} 5,899$ lebih besar dari t1- $\propto(2,002)$. Dalam hal ini $t_{\text {hitung }}$ berada pada daerah penolakan $H_{o}, H_{o}$ ditolak H1 diterima yang artinya model pembelajaran peer teaching memberikan pengaruh yang signifikan terhadap hasil belajar keterampilan bermain sepak bola.

Dengan demikian, dapat disimpulkan bahwa penelitian sebelumnya mengenai model pembelajaran peer teaching menjadi acuan penelitian model pembelajaran peer teaching berpengaruh terhadap peningkatan aspek afektif mahasiswa pada mata kuliah akuntansi keuangan program studi perbankan syariah Universitas Muhammadiyah Sumatera Utara.

\section{METODE PENELITIAN}

Rancangan penelitian yang digunakan adalah desain kelompok kontrol (non-ekuivalen control group design). Didalam desain ini penelitian menggunakan satu kelompok eksperimen dengan kelompok pembanding dan diawali dengan sebuah tes awal (pre test) yang diberikan kepada kedua kelompok. Kemudian diberikan perlakuan (treatment) di kelompok eksperimen. Penelitian kemudian diakhiri dengan post test yang diberikan kepada kedua kelompok (Sugiyono 2011). Pada desain ini, subjek tidak dikelompokkan secara acak, tetapi peneliti menerima keadaan subjek seadanya. 
Isra Hayati dan Dian Novianti Sitompul_Pengaruh Model Pembelajaran Peer Teaching Terhadap Peningkatan Aspek Afektif Mahasiswa Pada Mata Kuliah Akuntansi Keuangan Program Studi Perbankan Syariah Universitas Muhammadiyah Sumatera Utara

Pada penelitian ini terdapat pretes, perlakuan yang berbeda (treatment), dan postes. Secara singkat, desain penelitian ini adalah sebagai berikut: Kelas Eksperimen :

$\mathrm{O} \times \mathrm{O}$

O $\quad 0$

Keterangan:

O : Pretes atau postes.

$\mathrm{X} \quad$ : Pembelajaran dengan model pembelajaran peer teaching

------ : Subjek tidak dikelompokkan secara acak

Untuk memperoleh data dalam penelitian ini digunakan Angket untuk mengukur aspek afektif mahasiswa dengan menggunakan skala Likert sebanyak 15 instrumen. Dengan angket ini seseorang dapat diketahui tentang keadaan/ data diri, pengalaman atau pengetahuan sikap atau pendapatnya dan lain - lain (Arikunto, 2013).

Analisis data diambil melalui perhitungan hasil skor angket Untuk menemukan model pembelajaran Peer Teaching berpengaruh secara signifikan terhadap terhadap peningkatan aspek aspek afektif mahasiswa pada mata kuliah akuntansi keuangan digunakan uji T-formula pada t-test (Sudjana, 2011) adalah:

$$
t_{\text {hitung }}=\frac{x_{1-} x_{2}}{\left.\sqrt{\left(n_{1}\right.}-1\right) S_{1}+\left(n_{2}-2\right) S_{2}\left[\frac{1}{n_{1}}+\frac{1}{n_{2}}\right]}
$$

Sedangkan untuk mengetahui seberapa besar pengaruh model pembelajaran Peer Teaching berpengaruh secara signifikan terhadap aspek afektif mahasiswa pada mata kuliah akuntansi keuangan dilakukan dengan gain ternormalisasi:

Gain ternormalisasi (N-Gain) $=\frac{\text { skor postes }- \text { skor pretes }}{\text { skor ideal }- \text { skor pretes }}$ (Meltzer 2002).

Hasil perhitungan gain kemudian diinterpretasikan dengan menggunakan klasifikasi gain (Hake 1999) sebagai berikut:

Tabel 1 Klasifikasi $N$-Gain 


\begin{tabular}{|c|l|}
\hline $\begin{array}{l}\text { Besarnya } \\
\text { Gain } \mathbf{( g )}\end{array}$ & Interpretasi \\
\hline $0,7 \leq g \leq 1$ & Tinggi \\
\hline $0,3 \leq g<, 7$ & Sedang \\
\hline $0 \leq g<0,3$ & Rendah \\
\hline
\end{tabular}

\section{HASIL PENELITIAN DAN PEMBAHASAN}

\subsection{Analisis Uji Coba Angket Untuk Mengukur Aspek Afektif}

Uji coba angket dilakukan di kelas yang bukan merupakan kelas penelitian yang sudah mendapatkan pelajaran pada materi akuntansi keuangan yaitu pada semester III kelas A Pagi tahun akademik 2016/2017. Jumlah angket sebanyak 15 pernyataan yang mencakup aspek afektif mulai dari Receiving atau attending (sikap penerimaan atau memperhatikan), Responding (menanggapi), Valuing (penentuan sikap), Organization (sikap organisasi) dan Characterization by evalue or calue complex (sikap pembentukan pola hidup) dengan komposisi aspek masing masing $20 \%$ yang telah diuji validitas dan reliabilitas.

\subsection{Distribusi Data Di Kelas Eksperimen dan Kelas Kontrol}

Hasil analisis skor afektif kelas kontrol diperoleh faktor gain ( $\mathrm{g}$ ) sebesar 0,4096 yang tergolong peningkatan sedang sementara faktor gain (g) pada kelas eksperimen sebesar 0,6593 yang tergolong peningkatan sedang. Hasil analisis tersebut menunjukkan bahwa peningkatan aspek afektif kelas eksperimen lebih besar dibandingkan dengan kelas kontrol.

Perhitungan peningkatan aspek afektif selengkapnya dapat dilihat pada peningkatan aspek afektif berdasarkan nilai rata-rata pretest dan posttest disajikan pada Gambar grafik dibawah ini: 
Isra Hayati dan Dian Novianti Sitompul_Pengaruh Model Pembelajaran Peer Teaching Terhadap Peningkatan Aspek Afektif Mahasiswa Pada Mata Kuliah Akuntansi Keuangan Program Studi Perbankan Syariah Universitas Muhammadiyah Sumatera Utara

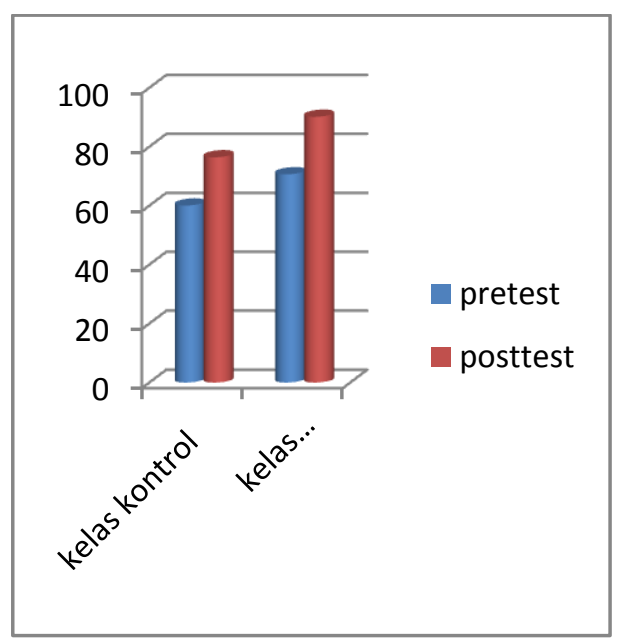

Gambar 1. Grafik Peningkatan Aspek Afektif

\subsection{Analisis Data Aspek Afektif}

\subsubsection{Uji Normalitas Gain di Kelas Kontrol}

Pengujian normalitas dilakukan untuk mengetahui data yang diperoleh berdistribusi normal atau tidak. Hasil pengolahan data tersebut dapat dilihat pada Tabel 2 dibawah ini:

Tabel 2. Uji Normalitas Gain Di Kelas Kontrol

\begin{tabular}{|llr|}
\hline & & \multicolumn{2}{|c|}{ Gain_Kontrol } \\
\hline $\mathrm{N}$ & & 29 \\
Normal & Mean &, 409641 \\
Parameter & Std. &, 0600486 \\
$\mathrm{~s}^{\mathrm{a}, \mathrm{b}}$ & Deviation &, 105 \\
Most & Absolute &, 105 \\
Extreme & Positive &,- 072 \\
Difference & Negative &, 105 \\
S & &, $200^{\mathrm{c}, \mathrm{d}}$ \\
Test Statistic & &, 2-tailed) \\
Asymp. Sig. (2-to
\end{tabular}


Isra Hayati dan Dian Novianti Sitompul_Pengaruh Model Pembelajaran Peer Teaching Terhadap Peningkatan Aspek Afektif Mahasiswa Pada Mata Kuliah Akuntansi Keuangan Program Studi Perbankan Syariah Universitas Muhammadiyah Sumatera Utara

Berdasarkan hasil uji normalitas dengan menggunakan uji OneSample Kolmogorov-Smirnov Test pada tabel nilai signifikasi pada kolom signifikasi data gain kelas kontrol adalah 0,200 nilai signifikasi lebih dari 0,05 maka hal ini menunjukkan bahwa data gain dikelas kontrol tersebut berdistribusi normal.

\section{b. Uji Normalitas Gain di Kelas Eksperimen}

Pengujian normalitas gain di kelas eksperimen dilakukan untuk mengetahui data yang diperoleh berdistribusi normal atau tidak. Pengujian normalitas terhadap kelas eksperimen pada distribusi data gain dilakukan dengan menggunakan program IBM SPSS 23.0 for windows dengan taraf signifikasi 0,05 .

Tabel 3

Uji Normalitas Gain di Kelas Eksperimen

Berdasarkan hasil uji normalitas dengan menggunakan uji One-

\begin{tabular}{|ll|r|}
\hline & \multicolumn{2}{|c|}{ Gain_Eksper } \\
\hline $\mathrm{N}$ & 34 \\
Normal $\quad$ Mean &, 659329 \\
Parameters & a, & Std. Deviation \\
$\mathrm{b}$ &, 1130786 \\
Most $\quad$ Absolute &, 079 \\
Extreme $\quad$ Positive &, 049 \\
Differences & Negative &,- 079 \\
Test Statistic &, 079 \\
Asymp. Sig. (2-tailed) &, $200^{\mathrm{c}, \mathrm{d}}$ \\
\hline
\end{tabular}

Sample Kolmogorov-Smirnov Test pada tabel nilai signifikasi pada kolom signifikasi data gain kelas eksperimen adalah 0,200 nilai signifikasi lebih dari 0,05 maka hal ini menunjukkan bahwa data gain dikelas eksperimen tersebut berdistribusi normal.

\section{c. Uji Homogenitas}


Isra Hayati dan Dian Novianti Sitompul_Pengaruh Model Pembelajaran Peer Teaching Terhadap Peningkatan Aspek Afektif Mahasiswa Pada Mata Kuliah Akuntansi Keuangan Program Studi Perbankan Syariah Universitas Muhammadiyah Sumatera Utara

\section{Tabel 6}

Homogenitas Kelas Eksperimen dan Kelas Kontrol

Kemampuan Afektif

\begin{tabular}{|r|r|r|c|}
\hline $\begin{array}{r}\text { Levene } \\
\text { Statistic }\end{array}$ & df1 & df2 & Sig. \\
\hline 6,083 & 1 & 61 &, 160 \\
\hline
\end{tabular}

Berdasarkan hasil uji homogenitas varians dengan menggunakan uji Levene pada tabel 5.16 nilai signifikasinya adalah 0,160. Karena diperoleh nilai signifikasinya lebih besar dari 0,05, maka dapat disimpulkan bahwa siswa kelas eksperimen dan kelas kontrol berasal dari populasi yang mempunyai varians yang sama, atau kedua kelas tersebut dapat dikatakan homogen.

\section{d. Uji Kesamaan Dua Rerata (Uji-t)}

Setelah kedua kelas tersebut berdistribusi normal dan memiliki varians yang homogen, maka selanjutnya dilakukan uji kesamaan dua rerata dengan uji-t dua pihak melalui program IBM SPSS 23.0 for windows menggunakan independent Sample T-Test dengan asumsi kedua varians homogen (equal varians assumed) dengan taraf signifikasi 0,05. Uji-t menunukkan bahwa nilai signifikansi pada signifikansi (2-tailed) adalah 0,001. Nilai signifikansi tersebut kurang dari 0,05. Maka dapat disimpulkan bahwa peningkatan Aspek Afektif mahasiswa pembelajarannya diterapkan model pembelajaran peer teaching lebih baik secara siginifikan dengan siswa yang pembelajarannya diterapkan model konvensional.

\subsection{Pembahasan Peningkatan Aspek Afektif Mahasiswa}

Berdasarkan analisis data skor angket setelah diberikan pembelajaran untuk mengukur aspek afektif diperoleh skor rata-rata setelah diberikan pembelajaran di kelas kontrol sebesar 81,3333 dan kelas eksperimen sebesar 93,3333. Rata-rata skor angket setelah diberikan pembelajaran mahasiswa untuk mengukur aspek afektif 
Isra Hayati dan Dian Novianti Sitompul_Pengaruh Model Pembelajaran Peer Teaching Terhadap Peningkatan Aspek Afektif Mahasiswa Pada Mata Kuliah Akuntansi Keuangan Program Studi Perbankan Syariah Universitas Muhammadiyah Sumatera Utara

tersebut untuk kelas eksperimen yang diberi perlakuan dengan model pembelajaran peer teaching lebih besar dari pada rata-rata skor angket setelah diberikan pembelajaran mahasiswa untuk mengukur aspek afektif tersebut untuk kelas kontrol. Hal ini menunjukkan bahwa model pembelajaran peer teaching dapat mempengaruhi aspek afektif mahasiswa yang diukur dari aspek Receiving atau attending (sikap penerimaan atau memperhatikan), Responding (menanggapi), Valuing (penentuan sikap), Organization (sikap organisasi) dan Characterization by evalue or calue complex (sikap pembentukan pola hidup) dengan komposisi aspek masing masing $20 \%$.

Berdasarkan uji uji kesamaan dua rerata skor angket setelah diberikan pembelajaran antara kelas kontrol dan kelas eksperimen dengan menggunakan uji-t pihak kanan, diperoleh $\mathrm{t}$ hitung $<\mathrm{t}$ tabel. Nilai signifikansi pada signifikansi (2-tailed) adalah 0,001. Nilai signifikansi tersebut kurang dari 0,05. Maka dapat disimpulkan bahwa Aspek Kognitif mahasiswa pada saat diterapkan model pembelajaran peer teaching lebih baik secara siginifikan dengan mahasiswa yang pembelajarannya diterapkan model konvensional. Hal ini menunjukkan model pembelajaran peer teaching berpengaruh terhadap peningkatan aspek afektif mahasiswa pada mata kuliah akuntansi keuangan program studi perbankan syariah.

Untuk melihat peningkatan aspek afektif yang dicapai oleh mahasiswa digunakan data $\mathrm{N}$-Gain ternormalisasi. Sehingga data yang dianalisis dalam penelitian ini adalah skor $N$-Gain yang telah ternormalkan. Rerata skor $\mathrm{N}$-Gain ternormalkan merupakan gambaran peningkatan aspek afektif mahasiswa baik dengan pembelajaran model pembelajaran peer teaching maupun dengan pembelajaran konvensional. Berdasarkan Tabel 5.10 di atas terdapat beberapa kesimpulan yang berkaitan dengan peningkatan aspek afektif mahasiswa yang dapat diungkap, yaitu: rerata skor $\mathrm{N}$-Gain aspek afektif mahasiswa di kelas eksperimen 0,6593 sedangkan rerata $N$-Gain aspek afektif mahasiswa di 
Isra Hayati dan Dian Novianti Sitompul_Pengaruh Model Pembelajaran Peer Teaching Terhadap Peningkatan Aspek Afektif Mahasiswa Pada Mata Kuliah Akuntansi Keuangan Program Studi Perbankan Syariah Universitas Muhammadiyah Sumatera Utara

kelas 17ontrol 0,4096. Peningkatan aspek afektif mahasiswa di kelas eksperimen dan 17ontrol tergolong ke dalam kategori sedang menurut Meltzer.

\section{KESIMPULAN DAN SARAN}

\subsection{Kesimpulan}

Berdasarkan uji kesamaan dua rerata skor angket setelah diberikan pembelajaran antara kelas kontrol dan kelas eksperimen dengan menggunakan uji-t pihak kanan, diperoleh $\mathrm{t}$ hitung $<\mathrm{t}$ tabel. Nilai signifikansi pada signifikansi (2-tailed) adalah 0,001. Nilai signifikansi tersebut kurang dari 0,05. Maka dapat disimpulkan bahwa Aspek Afektif mahasiswa pada saat diterapkan model pembelajaran peer teaching lebih baik secara siginifikan dengan mahasiswa yang pembelajarannya diterapkan model pembelajaran konvensional.

\subsection{Saran}

Berdasarkan kesimpulan di atas, maka penulis mengemukakan beberapa saran sebagai berikut:

1. Hasil penelitian ini menunjukkan bahwa pembelajaran dengan model pembelajaran peer teaching dapat meningkatkan aspek afektif mahasiswa. Oleh karena itu, bagi para dosen maupun guru hendaknya menjadikan pembelajaran dengan model pembelajaran peer teaching sebagai salah satu alternatif model pembelajaran yang digunakan di kelas.

2. Kemampuan afektif lainnya perlu dilakukan penelitian lanjutan untuk mengetahui peningkatan kemampuan afektif mahasiswa (ditinjau dari kemampuan afektif kelompok tinggi, menengah dan bawah) dengan menggunakan model pembelajaran peer teaching.

\section{DAFTAR PUSTAKA}

Airasian, Peter W., dkk. 2010. Kerangka Landasan untuk Pembelajaran, Pengajaran, dan Asesmen. Terjemahan A Taxonomy for Learning, Teaching, and Assesing: A Revision of Bloom's Taxonomy of Educational Objectives oleh Agung Prihantoro. Yogyakarta: Pustaka Pelajar.

Anita. 2008. Cooperative Learning: Mempraktikkan Cooperative Learning di Ruang - Ruang Kelas. Jakarta: PT Grasindo

Arikunto, Suharsimi. 2008. Penelitian Tindakan Kelas. Cetakan Ketujuh. 
Isra Hayati dan Dian Novianti Sitompul_Pengaruh Model Pembelajaran Peer Teaching Terhadap Peningkatan Aspek Afektif Mahasiswa Pada Mata Kuliah Akuntansi Keuangan Program Studi Perbankan Syariah Universitas Muhammadiyah Sumatera Utara

Jakarta: Bumi Aksara.

Arikunto, Suharsimi. 2013. Prosedur Penelitian (edisi revisi). Jakarta: Rineka Cipta.

Belkaoui, Ahmed R. 2001. Teori Akuntansi, Edisi 4, Jilid 2. Alih Bahasa Mawinta, Hajayanti Widiastuti, Heri Kurniawan, Alia Arisanti. Jakarta: Salemba Empat

Delima. 2011. Penilaian Hasil Proses Belajar Mengajar. Bandung: Remaja Rosdakarya.

Djalil. 2012. Metode Tutor Sebaya (Peer Teaching) Dengan BerbantuanMedia AudioVisual. Bandung: Falah Production

Fatirul, A. (2008)0. Cooperative Learning. diunduh 14 September 2015, http/trimanjuniarso.files. wordpress.com.

Hake, R. R. 1999. Analyzing Change/ Gain Score American Educational Research Methodolog, diunduh 14 September 2015, http://lists.asu.edu/cgi bin/wa?A2=ind9903\&L=aera d\&P=R6855

Huijser. 2008. Peer Assisted Learning in Fleximode: Developing an Online Learning Community. University of Southern Queensland.

Hwang,G.-J.,Yin,P.-Y.,Hwang,C.-W., \& Tsai,C.-C. 2008. An Enhanced Genetic Approachto Composing CooperatiOve Learning Groupsfor Multiple Grouping Criteria. Educational Technology \& Society, 11

(1) , 148 - 167.

Jagiyanto. 2006. Psikologi Kognitif, Yogyakarta: Pustaka Pelajar.

Lie. 2010. Mempraktekkan Cooperative learning di Ruang ruang Kelas. Jakarta: PT.Gramedia.

Meltzer, D.E. 2002. Relation between Student' Problem-Solving Performance and Representation FormatAmerican Journal of Physic. 73. No.5, 465.

Melvi. 2012. Diskusi Kelompok Terbimbing Metode Tutor Sebaya. Bandung: Yrama Widya

Mujhinem. 2010. Metode dan teknik Pembelajaran Partisipatif. Singaraja: Undiksha

Mulyasa, E. 2006. Kurikulum Tingkat Satuan Pendidikan. Bandung: PT Remaja Rosdak0arya

Nana. 2008. Dasar - dasar Proses Belajar Mengajar. Bandung: Sinar Baru Algensindo

Nurhadi,dkk. 2012. Pembelajaran Kontekstual dan Penerapannya dalam $K B K$. Malang: UMPress

Ornstein, Allan C. dan Thomas J. Lasley, II. 2000. Strategies for Effective TeachiOng. The Mc Graw-Hill Higher Education: USA.

Pujiono, S. 2008. Penguasaan Kosa kata dengan Strategi Jigsaw Pada Siswa SMP. Jurnal Teknodika, 4, 153-160.

Sari, N. 2009.Pengaruh Model Pembelajaran STAD dan Penguasaan Kosa kata Bahasa Inggris di Sekolah Dasar. Jurnal Teknodika, 7, No: 1,80 . 
Isra Hayati dan Dian Novianti Sitompul_Pengaruh Model Pembelajaran Peer Teaching Terhadap Peningkatan Aspek Afektif Mahasiswa Pada Mata Kuliah Akuntansi Keuangan Program Studi Perbankan Syariah Universitas Muhammadiyah Sumatera Utara

Semiawan. 2012. Strategi Pembelajaran Tutor Sebaya. Bandung: PT Remaja Rosdakarya.

Singgih D. 2013. Konseling dan Psikoterapi, Jakarta: Gunung Mulia

Sugiarto dkk. 2013. Akuntansi Keuangan. Universitas Terbuka: Jakarta

Sugiyono. 2011. Model Penelitian Kuantitatif Kualitatif. Bandung: Alfabeta

Yamin. 2007. Profesionalisasi Guru dan Implementasi KTSP. Jakarta: Gaung Persada Press 